\title{
Determination of Metaldehyde in Different Commercial Pesticide Formulations Using Green Analytical Procedure and Gas Chromatography Flame Ionization Detection
}

\author{
Marlena Płonka $^{1}$, Marek Miszczyk ${ }^{1 *}$, Patrycja Marczewska ${ }^{1,2}$ and Mieczyslaw Sajewicz ${ }^{2}$ \\ ${ }^{\prime}$ Pesticide Quality Testing Laboratory, Institute of Plant Protection-National Research Institute Sośnicowice Branch, Gliwicka 29, \\ 44-153 Sośnicowice, Poland \\ 'Department of General Chemistry and Chromatography, Institute of Chemistry, University of Silesia, Szkolna 9, 40-006 Katowice,
} Poland

Received: 25 June 2018; accepted: 25 June 2018

\begin{abstract}
Metaldehyde is a molluscicide allowed for use in the control of slugs and snails in agriculture and horticulture in many countries. A simple, fast, and precise gas chromatography method was developed and single-laboratory validated for determination of metaldehyde in different formulations of plant protection products. The proposed method involves extraction of active substance from samples by sonication with acetone and analysis using gas chromatography-flame ionization detection (GC-FID). The suggested analytical procedure is accurate, precise, and repeatable. Moreover, it is environmentally friendly and useful for laboratories as it uses a no time- and no solvent-consuming reference chromatography technique for quality control of commercially available pesticide formulations. Advantages of the proposed method are consistent with the ideas of sustainable development, which are in accordance with the principles of Green Analytical Chemistry. Analysis of real samples of commercial pesticide formulations confirmed that the proposed method is fit for its purpose.
\end{abstract}

Keywords: Pesticide, metaldehyde, quality control, gas chromatography, green analytical chemistry

\section{Introduction}

Metaldehyde (2,4,6,8-tetramethyl-1,3,5,7-tetraoxacyclo-octane) is a tetramer of acetaldehyde. Information about the slug-killing properties of metaldehyde was first published in 1936 [1]. It is a molluscicide with contact and stomach action-poisoned slugs secrete large quantities of slime, dehydrate, and diewhich has been used in the control of slugs and snails in agriculture and horticulture. Plant protection products with metaldehyde are produced in the form of granular bait (GB) and granule (GR), as well as a ready-to-use bait (RB) [1]

Data from January 2018 indicate that metaldehyde is approved for use in twenty five European Union (EU) countries [2]. Analysis of data regarding plant protection products approved for use in Poland in the most recent years indicates a significant increase in the number of products containing metaldehyde as an active substance, which are available on the Polish market. Figure 1 shows the number of metaldehyde preparations placed on the market in Poland in 2004-2017 (as of January each year) [3]. There was a sharp increase in the number of issued permits in 2015-2017, whereas from 2004 to 2014, the number of preparations available on the Polish market remained stable. In Poland, according to the registry of January 2018, pursuant to a permit issued by the Minister of Agriculture and Rural Development, there were 29 preparations approved for use, including $23 \mathrm{~GB}$ preparations, $4 \mathrm{RB}$ preparations, and 2 GR products. These products contain $25-50 \mathrm{~g} / \mathrm{kg}$ of metaldehyde [4]. The number of products is about half way in comparison with countries like Germany or Great Britain [5, 6].

\footnotetext{
*Author for correspondence: m.miszczyk@ior.gliwice.pl
}

Since metaldehyde formulations have been used for a number of years, a range of methods were developed and published for the determination of metaldehyde residues in different matrices including water, human serum, fruits, and vegetables. These include simple systems like gas chromatography with flame ionization detector (GC-FID) employed for determination of metaldehyde in animal materials or nitrogen-phosphorus detector (NPD) used upon prior metaldehyde derivatization in citrus fruit and tobacco plants [7-9]. Metaldehyde residues were also determined using more complex systems like gas chromatography coupled with mass spectrometry (GC-MS) (determination of metaldehyde in water and riverbed deposits in the case of metaldehyde poisonings and residue analyses in foods) [10-13], liquid chromatography coupled with tandem mass spectrometry (LC-MS/MS) (metaldehyde determination in vegetables, soil, and water) [14-19], and headspace gas-chromatography coupled with mass spectrometry (HS-GC-MS) (metaldehyde determination in human plasma) [20], as well as gas chromatography with a less popular rubidium sulfate alkali-flame ionization detector (AFD) [21].

The authors of this article are not aware of any recent publications concerning metaldehyde determination in formulations of plant protection products, which are currently available on the market. The subject matter literature references a method of metaldehyde determination in plant protection products using GC-MS with $m$-xylene as an internal standard and trichloromethane as a solvent (the authors were not able to access the full description of the above-mentioned method) [1]. This method, however, does not correlate in any way with the ideas of sustainable development, currently taking hold in a growing number of laboratories, in the form of the principles of Green Analytical Chemistry (GAC). According to the principles, one should (1) prefer direct techniques so as to

This is an open-access article distributed under the terms of the Creative Commons Attribution-NonCommercial 4.0 International License (https://creativecommons.org/licenses/by-nc/4.0/), which permits unrestricted use, distribution, and reproduction in any medium for non-commercial purposes, provided the original author and source are credited, a link to the CC License is provided, and changes - if any - are indicated. 


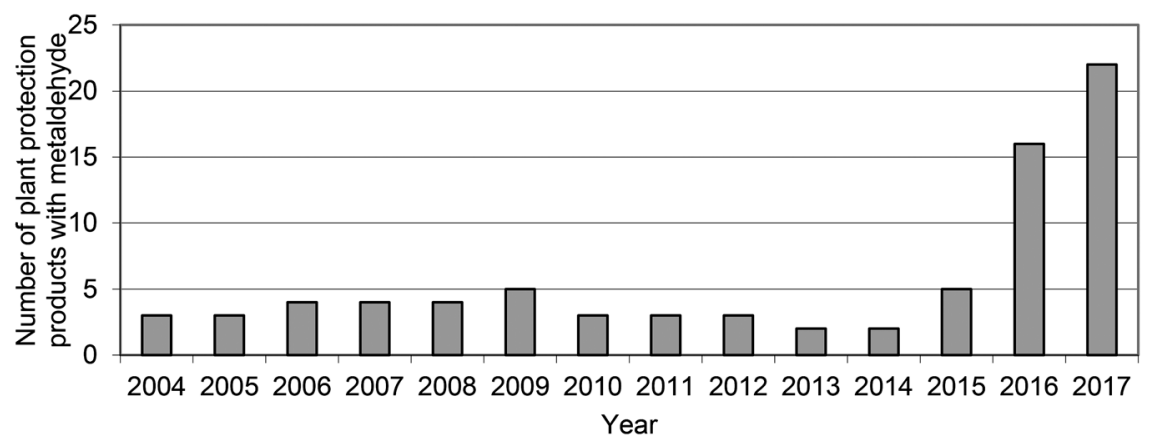

Figure 1. The number of metaldehyde preparations registered for use in Poland in 2004-2017

eliminate the step of sample preparation for analysis, (2) reduce the number and the volume of collected samples, (3) perform in situ measurements if possible, (4) integrate processes and analytical operations to reduce reagents and energy consumption, (5) employ automated and miniaturized methods, (6) resign from derivatization, (7) aim at reduction of generated analytical wastes and their proper neutralization, (8) select techniques enabling multi-analyte determination or multi-parameter measurement in a single run, (9) minimize energy consumption, (10) avoid using toxic reagents, and (11) increase the work safety of analytical chemists [22-25]. It is worth underlining that the European Union law according to Article 68 of the Regulation (EC) No 1107/2009 of the European Parliament and of the Council of 21 October 2009, concerning the placing of plant protection products on the market and repealing Council Directives 79/117/EEC and 91/414/EEC, mandates the member states to perform official control of pesticides which are being introduced on the market [26]. A key component of the control is the quality testing of samples taken among commercially available products, verifying that the products are of adequate quality, i.e., they comply with the requirements and criteria set during the registration process. The control measure is designed to prevent the use of noncompliant pesticides, which could have an adverse or harmful effect on crops, animals, the environment, and humans [26].

The aim of the study was to develop a simple, fast, inexpensive, and GAC-compliant method for the determination of metaldehyde, which could be easily adopted in routine activities of a quality control laboratory.

\section{Experimental}

2.1. Reagents and Materials. The analytical standard of metaldehyde (99.0\%) was obtained from Dr. Ehrenstorfer (currently LGC) (Augsburg, Germany). Acetone (for residue pesticide analysis) was purchased from Avantor Performance Materials Poland S.A. (Gliwice, Poland). Commercial formulations containing metaldehyde in the form of GB, GR, and RB were acquired from the Polish market. The plant protection products with metaldehyde available in Poland at the time, when this work was carried out, contained $25-50 \mathrm{~g} / \mathrm{kg}$ of active substance.

2.2. Preparation of Reference Solutions. Solutions of analytical standard of metaldehyde were prepared at the concentrations of $1 \mathrm{mg} / \mathrm{mL}$ by weighting an appropriate amount of compound and diluting it with acetone.

2.3. Sample Preparation. For the determination of the active substance, about $10 \mathrm{~g}$ of a formulation was weighted on a precision balance and ground using the pulse function of an electric laboratory grinder. A part of the pre-ground sample was then transferred into a mortar and further processed into fine powder. Then, an appropriate amount of a commercial formulation was weighted to obtain the concentration of approximately $1 \mathrm{mg} / \mathrm{mL}$ of the active substance in the solution. Three portions of each sample were weighted and diluted with acetone to the final volume, then sonicated for $10 \mathrm{~min}$ and allowed to cool to room temperature. Prior to gas chromatography analysis, cooled samples were filtered into chromatographic vials with the use of polytetrafluoroethylene (PTFE) filters $(0.45 \mu \mathrm{m})$. Analysis of each sample was carried out in triplicate.

2.4. Instrumentation and Conditions. Separation, identification, and quantification were carried out using an Agilent 7890 series gas chromatograph, equipped with flame ionization detector (FID) (Agilent Technologies, Palo Alto, CA, USA). Analyte was separated with an HP-5 capillary column $(30 \mathrm{~m} \times 0.25 \mathrm{~mm} \times 0.25 \mu \mathrm{m})$ (Agilent Technologies, Folsom, CA, USA). Extracts $(1 \mu \mathrm{L})$ were injected in the split mode (split ratio of 1:50) using a standard split/splitless

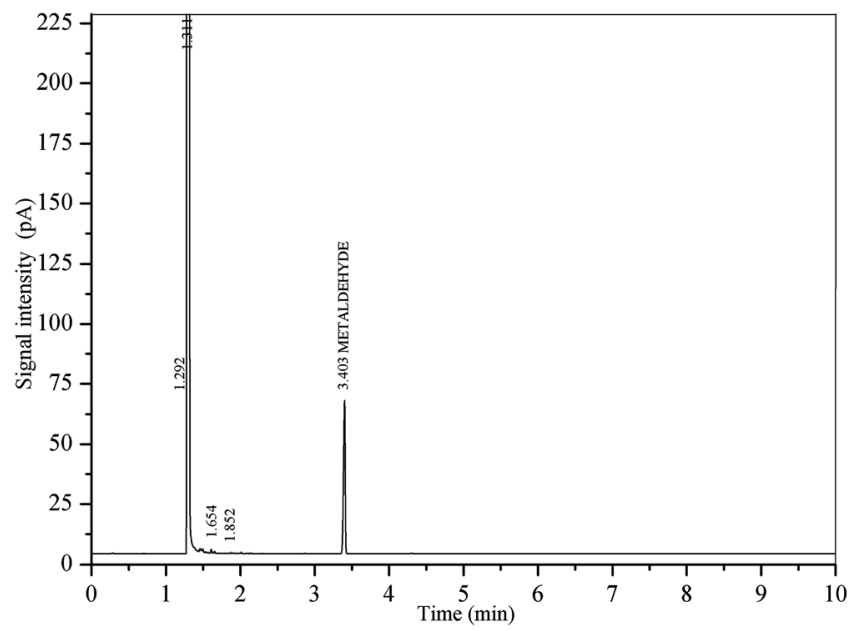

Figure 2. An example of a GC-FID chromatogram for a sample of a plant protection product containing metaldehyde $\left(t_{\mathrm{R}}=3.403 \mathrm{~min}\right)$ 
Table 1. Linearity parameters obtained for GC-FID analysis of metaldehyde in plant protection products formulations

\begin{tabular}{lcccccc}
\hline Substance & Calibration levels & Slope $a \pm \mathrm{SD}_{\mathrm{a}}$ & Intercept $b \pm \mathrm{SD}_{\mathrm{b}}$ & Correlation coefficient & $S_{\mathrm{y} / \mathrm{x}}{ }^{a}$ & $\mathrm{Concentration} \mathrm{range}[\mathrm{mg} / \mathrm{mL}]$ \\
\hline $\begin{array}{l}\text { Metaldehyde } \\
{ }^{a} \text { Residual standard deviation. }\end{array}$ & 5 & $150.93 \pm 6.37$ & $-4.83 \pm 6.51$ & 0.997 & 3.02 & $0.7-1.3$ \\
\hline
\end{tabular}

injector kept at the temperature of $280^{\circ} \mathrm{C}$. High purity helium (99.999\%, Messer Group GmbH, Bad Soden, Germany) was used as carrier gas with a constant flow of $1.76 \mathrm{~mL} / \mathrm{min}$. The column oven temperature was held at a constant temperature of $100{ }^{\circ} \mathrm{C}$. The total run time was $10 \mathrm{~min}$. The detector temperature was kept at $300{ }^{\circ} \mathrm{C}$. Instrument control and data processing was carried out using an Agilent GC ChemStation B.04.03 (Agilent Technologies, Palo Alto, CA, USA).

\section{Results and Discussion}

Method validation was realized according to SANCO/3030/ 99 rev. 4 and CIPAC guidelines on the basis of the following parameters: specificity, linearity, precision, and accuracy. Generally blank formulations of plant protection products are not available; therefore, a standard addition method was used for estimation of accuracy. In accordance with the abovementioned guidelines, establishing limits of quantification (LOQ) is not required for an active substance, and hence it was not performed [27-29].

Specificity is the ability of a method to distinguish between the analyte being measured and other substances, based upon sufficient characteristics of the analyte as to make the results completely specific to the analyte, irrespective of the characteristics of other materials present [27]. Since blank pesticide formulations were not available, the lack of interference was demonstrated in the analysis of formulations samples, solvent, and standard solutions. Figure 2 shows a typical result of separation of detected compounds.

Linearity is the ability of a detection system, within a defined range, to produce an acceptable linear correlation between the test results and the concentration of analyte in the sample. The linearity of response was assessed, considering the range of nominal concentration of the target analyte in the analyzed matrices $\pm 30 \%$ (according to the requirements, the minimum range should be $\pm 20 \%$ ). Five working standard solutions of metaldehyde were prepared at concentrations of $0.70,0.85,1.00,1.15$, and $1.30 \mathrm{mg} / \mathrm{mL}$. Data was collected from six injections at each calibration level. Linear regression performed with the use of least squares method demonstrated satisfactory linear relationship of the analyte response with correlation coefficient $\geq 0.99$. The obtained linearity parameters are summarized in Table 1.

Table 2. Precision for tested plant protection products

\begin{tabular}{lccc}
\hline $\begin{array}{l}\text { Plant protection } \\
\text { product }\end{array}$ & $\begin{array}{c}\text { Declared concentration } \\
\text { of metaldehyde [\%] }\end{array}$ & $\begin{array}{c}\% \\
\mathrm{RSD}_{\mathrm{r} \text { teoretical }}\end{array}$ & $\mathrm{RSD}_{\mathrm{r} \text { experimental }}$ \\
\hline $\begin{array}{l}\text { Product A } \\
\text { formulation GB }\end{array}$ & 5.0 & 2.10 & $1.15-2.07$ \\
$\begin{array}{l}\text { Product B } \\
\text { formulation GR }\end{array}$ & 3.0 & & $1.35-1.37$ \\
$\begin{array}{l}\text { Product C } \\
\text { formulation GB }\end{array}$ & 3.0 & & 0.81 \\
$\begin{array}{l}\text { Product D } \\
\text { formulation GB }\end{array}$ & 3.0 & 2.27 & $1.34-1.68$ \\
$\begin{array}{l}\text { Product E } \\
\text { formulation GB }\end{array}$ & 3.0 & & $0.55-1.14$ \\
$\begin{array}{l}\text { Product F } \\
\text { formulation GB }\end{array}$ & 3.0 & & $0.84-1.04$ \\
$\begin{array}{l}\text { Product G } \\
\text { formulation RB }\end{array}$ & 2.5 & 2.33 & 1.16 \\
$\begin{array}{l}\text { Product H } \\
\text { formulation GB }\end{array}$ & 3.0 & 2.27 & $2.05-2.11$ \\
\hline
\end{tabular}

The precision of the method was determined by analysis of six different sample solutions prepared from the same batch of a pesticide formulation. Suitability criteria of precision were based on the modified Horwitz equation [27]. The obtained experimental $\mathrm{RSD}_{\mathrm{r}}$ value was compared with the $\mathrm{RSD}_{\mathrm{r}}$ value calculated from the modified Horwitz equation (Eq. 1).

$$
\operatorname{RSD}_{r}(\%)=\operatorname{RSD}_{R}(\%) \times 0.67
$$

where

$$
\operatorname{RSD}_{R}(\%)=2^{(1-0.5 \log C)}
$$

where $C$ is the concentration of an analyte in a sample expressed as a decimal mass fraction, $\mathrm{RSD}_{\mathrm{r}}$ is the repeatability relative standard deviation, and $\mathrm{RSD}_{\mathrm{R}}$ is the inter-laboratory relative standard deviation.

Precision was considered acceptable if the experimental $\mathrm{RSD}_{\mathrm{r}}$ value was lower than the calculated $\mathrm{RSD}_{\mathrm{r}}$ value. Precision assessed for metaldehyde determinations in plant protection products is given in Table 2. The obtained results demonstrate adequacy of the proposed method for the intended application.

Accuracy is the degree to which the determined concentration/content of an analyte in a sample corresponds to the true value [27]. In this study, blank (i.e., analyte-free) formulations were not available, and the accuracy of measurements was determined by recovery studies applying the standard addition method. Three portions of each pesticide formulation in acetone containing $1 \mathrm{mg}$ of metaldehyde per $1 \mathrm{~mL}$ of solution were prepared, separately for GB, GR, and RB formulations. Then, $0.0,1.5$, and $3.0 \mathrm{~mL}$ of the standard solution with appropriate concentration of metaldehyde were added, and finally, the mixture was diluted to $10 \mathrm{~mL}$ with acetone. Recoveries were determined in three replicates at two spiking levels. The spiking level depended on the amount of the active substance present in the formulation. According to the SANCO guidelines, a spiking range of $1-10 \%$ should give recovery of $98-102 \%$. All obtained recovery values fell within the respective acceptance ranges (Table 3 ).

Table 3. Accuracy expressed as the percent recovery of a spike

\begin{tabular}{lccc}
\hline $\begin{array}{l}\text { Plant protection } \\
\text { product }\end{array}$ & $\begin{array}{c}\text { Declared concentration } \\
\text { of metaldehyde [\%] }\end{array}$ & $\begin{array}{c}\text { Accepted } \\
\text { recovery [\%] }\end{array}$ & $\begin{array}{c}\text { Recovery } \\
{[\%]}\end{array}$ \\
\hline $\begin{array}{l}\text { Product A } \\
\text { formulation GB } \\
\text { Product B }\end{array}$ & 5.0 & & $100.65-102.28$ \\
$\begin{array}{l}\text { formulation GR } \\
\text { Product C } \\
\text { formulation GB }\end{array}$ & 3.0 & $100.27-101.98$ \\
$\begin{array}{l}\text { Product D } \\
\text { formulation GB } \\
\text { Product E }\end{array}$ & 3.0 & $97.18-98.61$ \\
$\begin{array}{l}\text { formulation GB } \\
\text { Product F } \\
\text { formulation GB }\end{array}$ & 3.0 & $97-103$ & $100.02-101.24$ \\
$\begin{array}{l}\text { Product G } \\
\text { formulation RB }\end{array}$ & 3.0 & $99.47-101.68$ \\
$\begin{array}{l}\text { Product H } \\
\text { formulation GB }\end{array}$ & 3.0 & $97.40-99.64$ \\
\hline
\end{tabular}


Table 4. Concentration of metaldehyde in difference plant protection products

\begin{tabular}{|c|c|c|c|c|}
\hline $\begin{array}{l}\text { Plant protection } \\
\text { product }\end{array}$ & $\begin{array}{l}\text { Number of analyzed } \\
\text { pesticides }\end{array}$ & $\begin{array}{l}\text { Declared concentration of } \\
\text { metaldehyde [\%] }\end{array}$ & $\begin{array}{l}\text { Concentration of metaldehyde in } \\
\text { analysed samples }[\%]^{a} \pm \mathrm{SD}\end{array}$ & $\begin{array}{l}\text { Accepted range of } \\
\text { metaldehyde [\%] }\end{array}$ \\
\hline $\begin{array}{l}\text { Product A } \\
\text { formulation GB }\end{array}$ & 4 & 5.0 & $\begin{array}{l}4.84 \pm 0.06 \\
4.93 \pm 0.08 \\
5.07 \pm 0.08 \\
5.16 \pm 0.06\end{array}$ & {$[4.8-5.2]$} \\
\hline $\begin{array}{l}\text { Product B } \\
\text { formulation GR }\end{array}$ & 3 & 3.0 & $\begin{array}{l}3.01 \pm 0.03 \\
3.05 \pm 0.03 \\
3.08 \pm 0.04\end{array}$ & {$[2.3-3.3]$} \\
\hline $\begin{array}{l}\text { Product C } \\
\text { formulation GB }\end{array}$ & 1 & 3.0 & $2.71 \pm 0.02$ & {$[2.3-3.3]$} \\
\hline $\begin{array}{l}\text { Product } D \\
\text { formulation GB }\end{array}$ & 2 & 3.0 & $\begin{array}{l}2.77 \pm 0.05 \\
3.04 \pm 0.07\end{array}$ & {$[2.3-3.3]$} \\
\hline $\begin{array}{l}\text { Product E } \\
\text { formulation GB }\end{array}$ & 3 & 3.0 & $\begin{array}{l}2.73 \pm 0.02 \\
2.81 \pm 0.02 \\
2.88 \pm 0.04\end{array}$ & {$[2.3-3.3]$} \\
\hline $\begin{array}{l}\text { Product F } \\
\text { formulation } \mathrm{GB}\end{array}$ & 2 & 3.0 & $\begin{array}{l}2.73 \pm 0.04 \\
3.08 \pm 0.04\end{array}$ & [2.3-3.3] \\
\hline $\begin{array}{l}\text { Product } \mathrm{G} \\
\text { formulation } \mathrm{RB}\end{array}$ & 1 & 2.5 & $2.54 \pm 0.02$ & {$[2.25-2.75]$} \\
\hline $\begin{array}{l}\text { Product } \mathrm{H} \\
\text { formulation GB }\end{array}$ & 2 & 3.0 & $\begin{array}{l}2.82 \pm 0.03 \\
3.13 \pm 0.02\end{array}$ & {$[2.3-3.3]$} \\
\hline${ }^{a}$ Each reporte & the mean $\pm \operatorname{SD}(n=6$ & & & \\
\hline
\end{tabular}

Data obtained for measurements of the spiked samples were also used to determine the linearity of response. The linearity fit was good and equal to minimum $r=0.9981$ for GB formulation, $r=0.9929$ for $\mathrm{GR}$, and $r=0.9934$ for RB formulation, which indicated that the instrument response to the analyte in the spiked samples resulted solely from the change in the analyte concentration. This also provided a confirmation of the specificity of the method, as the contribution of matrix components to the instrument response was negligible.

In conclusion, validation of the developed method showed highly satisfactory results for all the required parameters of analytical performance.

To demonstrate applicability of the developed and validated method, real samples of commercial pesticide formulations containing $25 \mathrm{~g} / \mathrm{kg}$ to $50 \mathrm{~g} / \mathrm{kg}$ of metaldehyde were analyzed to determine the concentration of the active substance. An examplary GC-FID chromatogram is shown in Figure 2. Eighteen formulations containing metaldehyde available on the Polish market were analyzed; the obtained results are shown in Table 4.

The tested formulations were produced by different manufacturers and represent eight products marked by letters $\mathrm{A}-\mathrm{H}$. The results of determination indicated that the active substance was within the acceptable range for all the samples.

\section{Conclusions}

The proposed GC-FID method for quality control of plant protection products with metaldehyde as an active substance was developed and validated according to the EU reference document recommendations [27]. The proposed approach can be easily implemented in control laboratories of member states. Also, the utility of the developed procedure can be verified by laboratories of third countries. Such compliance combined with the fact that the method provides for a fast, single analytical course results related to both the quality and quantity of an active substance makes the proposed method suitable for control testing of metaldehyde pesticides by laboratories working according to EU standards. It should also be underlined that the outline of a method for the determination of metaldehyde mentioned in the Pesticide Manual recommends using expensive and complicated analytical techniques (i.e., GC-MS) and hazardous chemicals (i.e., m-xylene and trichloromethane) [1]. The developed method could be relatively easily adopted even in not-very-well-equipment laboratories because it uses GC-FID, which is an easy, fast, and inexpensive technique. It is also worth mentioning that the proposed method for the determination of metaldehyde utilizes small amounts of low-toxicity reagents, i.e., acetone, involves an uncomplicated sample preparation step and uses a relatively simple, inexpensive, and commonly available analytical technique. Therefore, it is in line with the idea of sustainable development propagated, among others, by the socalled Green Analytical Chemistry principles. The proposed approach allowed the determination of metaldehyde in a complex mixture without interference from other components including degradation products, impurities, and formulation additives.

\section{References}

1. MacBean, C. A World Compendium, The Pesticide Manual; 16th edn. BCPC: Alton; 2012.

2. EU Pesticides database, http://ec.europa.eu/food/plant/pesticides/eupesticides-database/public/?event=homepage\&language=EN (accessed May 2018). 3. Institute of Plant Protection - National Research Institute, Zalecenia ochrony roślin. Cześć I. Wykaz środków ochrony roślin; Institute of Plant Protection- National Research Institute: Poznań; 2004-2017.

4. Ministry of Agriculture and Rural Development, https://bip.minrol.gov. pl/Informacje-Branzowe/Produkcja-Roslinna/Ochrona-Roslin/Rejestr-SrodkowOchrony-Roslin (accessed May 2018).

5. Bundesamt für Verbraucherschutz und Lebensmittelsicherheit, https:// apps2.bvl.bund.de/psm/jsp/index.jsp?modul=form (accessed May 2018).

6. Pesticides Register of UK, Health and Safety Executive. Plant Protection Products with Authorisation for use in the UK, https://secure. pesticides.gov.uk/pestreg/ProdSearch.asp (accessed May 2018).

7. Booze, T. F.; Oehme, F. W. J. Anal. Toxicol. 1985, 9, 172-173.

8. Iwata, Y.; Carman, G. E.; Dinoff, T. M.; Gunther, F. A. J. Agric. Food Chem. 1982, 30, 606-608.

9. Zhang, X. Y.; Dai, X. F. Chin. J. Pest. Science 2006, 8, 344-348.

10. Coloso, R. M.; Borlongan, I. G.; Blum, R. A. Crop Protect 1998, 17, 669-674.

11. Zhang, Z.; Lefebvre, T.; Kerr, C.; Osprey, M. J. Sep. Science 2014, 37, 3699-3705.

12. Jones, A.; Charlton, A. J. Agric. Food Chem. 1999, 47, 4675-4677.

13. Zhang, H.; Wang, C.; Lu, H.; Guan, W.; Ma, Y. Ecotoxicol. Environ. Saf. 2011, 74, 1653-1658.

14. Dong, B.; Shao, X.; Lin, H.; Hu, J. Food Chem. 2017, 229, 604-609.

15. Ma, Y. Q.; Wu, X. L.; Zheng, Z. T.; Yang, Y.; Wang, C.; Zhang, H. Y.; Meng, L. X. Adv. Mater. Res. 2012, 347-353, 1987-1993.

16. Zang, H. Y.; Wang, C.; Xu, P. J.; Ma, Y. Q. Food Addit. Contam. Part $A$ 2011, 28, 1034-1040.

17. Li, C.; Wu, Y. L.; Yang, T.; Zhang, Y. Chromatographia 2010, 72, 987-991.

18. Schumacher, M.; Castle, G.; Gravell, A.; Mills, G. A.; Fones, G. R. MethodsX 2016, 3, 188-194.

19. Li, X.; Peng, T.; Jia, R.; Chen, D.; Dai, H. Food Science 2011, 32, 224-228.

20. Saito, T.; Morita, S.; Motojyuku, M.; Akieda, K.; Otsuka, H.; Yamamoto, I.; Inokuchi, S. J. Chromatogr. B 2008, 875, 573-576.

21. Selim, S.; Seiber, J. N. J. Agric. Food Chem. 1973, 21, 430-433. 
22. American Chemical Society, 12 Principles of Green Chemistry, https:// www.acs.org/content/acs/en/greenchemistry/what-is-green-chemistry/principles/ 12-principles-of-green-chemistry.html (accessed May 2018).

23. Tobiszewski, M.; Mechlińska, A.; Namieśnik, J. Chem. Soc. Rev. 2010, $39,2869-2878$.

24. Namieśnik, J. J. Sep. Science 2001, 24, 151-153.

25. Tobiszewski, M.; Namieœnik, J. Trends Anal. Chem. 2012, 35, 67-73.

26. European Commission, Regulation (EC) No $1107 / 2009$ of the European Parliament and of the Council of 21 October 2009 concerning the placing of plant protection products on the market and repealing Council Directives 79/ 117/EEC and 91/414/EEC), http://eur-lex.europa.eu/legal-content/EN/TXT PDF/?uri=CELEX:32009R1107\&from=EN (accessed May 2018).
27. Directorate General Health and Consumer Protection, SANCO/3030/99 rev. 4. Technical Material and Preparations, https://ec.europa.eu/food/sites/ food/files/plant/docs/pesticides_ppp_app-proc_guide_phys-chem-ana_tech-matpreps.pdf (accessed May 2018)

28. Collaborative International Pesticide Analytical Council, Guidelines on method validation to be performed in support of analytical methods for agrochemical formulations, http://cipac.org/images/pdf/validat.pdf (accessed May 2018).

29. Collaborative International Pesticide Analytical Council, Guidelines for analytical methods for the determination of relevant impurities referred to in FAO and/or WHO specifications for pesticide technical grade active ingredients and formulations, http://cipac.org/images/pdf/CIPAC Guideline\%20Relevant \%20impurities_June\%202009.pdf (accessed May 2018). 